${ }^{\text {I }}$ Universidade de Brasília, Departamento de Sociologia, Brasil

nilos@uol.com.br

Edson Farias ${ }^{\prime}$

\title{
O SABER CARNAVALESCO: CRIAÇÃO, ILUSÃO E TRADIÇÃO NO CARNAVAL CARIOCA'
}

Na abertura do programa Roda Viva, da TV Cultura, levado ao ar no dia 22 de março de 20I I, a apresentadora Marília Gabriela informava que, naquela noite, o entrevistado seria o representante de uma profissão existente apenas no Brasil:

O país do carnaval inventou o carnavalesco. O cara que literalmente coloca o samba na Avenida, seja ela a Marquês de Sapucaí, no Rio de Janeiro, ou o Sambódromo do Anhembi, em São Paulo. O nosso convidado desta noite é Paulo Barros, um dos mais importantes, um dos mais brilhantes representantes do trabalhador da folia.

Logo na sequência, a jornalista resumiu o currículo do entrevistado, Paulo Barros, destacando suas qualidades para justificar a notoriedade por ele obtida, a ponto de levá-lo ao centro das atenções naquele programa de TV:

No carnaval deste ano [20II] ele foi vice-campeão, mas, mais uma vez, ele foi ovacionado pelo público. Paulo Barros perseguiu o sucesso na Avenida por mais de uma década e fez seu nome com lances de ousadia, surpresa, polêmica, irreverência e muita, muita criatividade. Ele inovou os desfiles com elogiadíssimas alegorias humanas. E, no ano passado, foi campeão apresentando truques de ilusionismo na comissão de frente.

No decorrer do programa, as perguntas formuladas pelos entrevistadores tiveram por objeto, sobretudo, a natureza da profissão de carnavalesco, ressaltando a cumplicidade, nela estabelecida, entre "inovação" e "criatividade". Não por coincidência, tal aproximação faz eco com proposições de 
alguns intérpretes do contemporâneo (Roberts, 2003: 85-95) que definem um e outro traço como ícones da "nova economia", a qual seria movida à base da orientação cibernética alimentada pela informação, manifestando as condições de um capitalismo cultural ou estético, no qual prevaleceriam comércio e circulação de imagens. Algo assim estando, segundo os mesmos intérpretes, na contrapartida da ampliação de parcelas da divisão técnica e social do trabalho dedicadas aos ramos profissionais de realização da aparência, os quais se incluem no domínio das prestações de serviços do entretenimento. ${ }^{2}$ Logo, também, não fora gratuita a menção feita por Marília Gabriela ao fato de Paulo Barros cumprir, durante o ano, uma agenda de palestras em workshops. Nessas situações, segundo ela, suas falas explicam o próprio ofício de carnavalesco para interessados, em números cada vez maiores. Inserindo-se, lembrou então, ao lado das funções como a de chefe de cozinha e profissionais da moda, no rol de atividades em ascensão na escolha de jovens de classe média, em especial por conta dos rendimentos que poderiam variar entre $\mathrm{R} \$$ 50 a R\$ 600 mil. Na resposta, contudo, Paulo Barros sublinhou se tratar de uma profissão "limitada", para a qual não existem cursos técnicos nem superiores. ${ }^{3}$ Observou, ainda, que o aprendizado se faz na frequência aos barracões, ou seja, nos locais de fabrico das alegorias e fantasias. Ele mesmo, prosseguiu, iniciou por volta dos I5/16 anos de idade, no barracão da Beija-Flor, quando ainda era desfilante da escola de samba de Nilópolis, sua cidade natal, e onde morou até o momento do ingresso na companhia aérea Varig, onde foi comissário de bordo por quinze anos, após abandonar o curso de arquitetura. Nesse instante, uma vez mais Marília Gabriela intervém, relatando que, em certa entrevista, o lendário carnavalesco Joãosinho Trinta recordou do garoto Paulo Barros "fuçando" tudo no barracão. A frase o fez sorrir, para em seguida confirmar: "Sempre fucei muito".

Os conteúdos dessas falas, mesmo a situação da entrevista, contêm dois pontos confluentes que motivam os objetivos perseguidos ao longo deste texto. De um lado, remetem às comunicações entre diferentes gerações e as linhagens estabelecidas nos meandros do mundo artístico específico da arte do carnaval, com seus oficiais, regras, instâncias de reconhecimento e mercados, na medida em que a função de carnavalesco se realiza nas suas injunções sobre a continuidade protocolar do gênero artístico-cultural "desfile de carnaval" (Farias, 2006: 266-323). Nesse ofício se fundem as tarefas de figurinista e cenógrafo com as de um diretor de cena na construção de significações plásticas, para as quais são reunidas competências literárias e dramatúrgicas. Por outro lado, despertam a curiosidade acerca do vínculo estabelecido entre a arte do carnavalesco e os aportes técnicos de que este lança mão na execução dos seus projetos anuais de considerar a passarela do samba como um complexo estético móvel e efêmero, com a finalidade de contar/apresentar um enredo para uma plateia cujo contingente vaza o local 
imediato de assistência, mediante a ecologia sociotécnica das mídias. A audiência, hoje, é calculada em mais de uma centena de milhões de telespectadores e está inserida em mercados brasileiros e internacionais. Isso chama a atenção, ao correlacionar as atividades próprias do ofício de carnavalesco no sistema de práticas lúdico-artísticas que definem a natureza expressivo-comunicacional do evento; natureza que participa da cadeia institucional amplíssima do entretenimento, com o ajuste entre produção, circulação e consumo de bens simbólicos na esfera pública global atravessada pelas tramas monetárias e financeiras da economia capitalista.

Neste artigo, iremos apenas tangenciar este último aspecto, embora o saibamos indissociável de uma agenda sociológica da cultura contemporânea, quando se trata de apreender e conceituar os elos estabelecidos entre expressões lúdico-artísticas com específico padrão de regulação emocional posto na contrapartida da reorientação de modos de simbolização pelos mecanismos institucionais que ora coordenam e regulam produção, fluxo e acesso aos bens culturais. Mas se nossa expectativa, aqui, é introduzir novos elementos analíticos à discussão de metamorfoses semânticas e funcionais de ideários e interesses artísticos em meio ao deslocamento de estruturas sociais, nos voltaremos tão somente à dinâmica que envolve posse e atualização criativa de legados sociossimbólicos intergeracionais, mas no escopo de processos de reposição diferenciada de sistemas sociais. Nesse sentido, em termos metodológicos, perseguiremos a meta de nos aproximar da natureza da experiência e das características dos fenômenos estéticos, entendendo ambos como elementos decisivos de um domínio particular dotado de um regime singular no tocante a valores, interesses e práticas, ainda que cada vez mais relevante da vida social contemporânea (Becker, 20I0; Heinichi, 2008:I4-I5; IO3-II5). Contudo, as prioridades de uma sociologia da arte estão subordinadas, no desenrolar da argumentação, ao empenho de articular as propriedades das coisas, considerando as representações nelas inseridas, às tramas das interdependências sociofuncionais que coagulam personalidades autoidentificadas como a de produtores artísticos reconhecidas por seus pares, intermediários, financiadores e expectadores (Bourdieu, I996: 209-318).

Desse modo, para abordar o valor conferido ao tipo de saber intrínseco à competência em iludir no exercício do ofício do carnavalesco, levamos em conta que as atividades aplicadas profissionalmente são conjuntos de funções realizadas entre pessoas, em resposta ao quadro de necessidades definido e reiterado em um contexto sócio-histórico (Elias, 2006: 89). O objetivo é apreender a composição dos encadeamentos intergeracionais em que se constitui a recursividade estrutural da ação/função do carnavalesco como elemento na afirmação do entretenimento como dimensão sistêmica do padrão societário e cultural da modernidade, em se tratando da experiência histórica na cidade do Rio de Janeiro, nas últimas décadas do século XX e no 
limiar do presente século. A tônica analítica estará depositada na maneira como esse saber relativo à estética barroca dos efeitos e excessos visuais se inscreve na problemática da permanência de uma diferencialidade funcional. $\mathrm{E}$, ao mesmo tempo, em que repercute a perenidade adquirida por um padrão de conduta artística em meio às alterações que envolvem a gama de interesses e ideias relacionada aos tantos planos constituintes do evento desfile das escolas de samba. Assim, no desenvolvimento do texto, retomaremos o elo estabelecido entre fazeres artísticos e o tema da técnica na contrapartida das confluências dos esquemas mercantis e profissionais vinculados ao âmbito das aparências, em particular aquele das expressões culturais que compõem situações sociocomunicativas nos arranjos societários modernos, onde se difundem tecnologicamente conteúdos informacionais a públicos indeterminados (Luhmann, 2005: I5-I7).

Calcado nos resultados de pesquisas em fontes historiográficas e documentais, além de observação participante, incluindo a realização de entrevistas semiestruturadas, e o recurso a materiais audiovisuais disponíveis na plataforma de vídeos Youtube, na Internet, o artigo está dividido em duas partes. A primeira se ocupa do valor depositado na ideia de ilusão na arte do carnavalesco, intrínseca ao escopo das técnicas modalizadas na realização da forma significante do seu fazer estético, mas para isto considerando a inserção desse ofício no gênero desfile de carnaval mediante o artefato cultural da alegoria. Na segunda, visamos ao processo de explicitação da linha de conduta do carnavalesco, levando em conta a transmissão de saberes entre duas gerações no ofício de carnavalesco, com o propósito de observar em que medida a atualização dessas memórias funcionais compreende reescalonamentos referidos à combinação dos agenciamentos nas aplicações técnicas de saberes com injunções sistêmicas. Deste modo, serão focados momentos da materialidade visual apresentada nos desfiles assinados tanto por Joãosinho Trinta como por Paulo Barros. Celebrado como o herdeiro contemporâneo da tradição da arte do carnaval, importa observar como, em sintonia com o estilo legado de João Trinta, nas elaborações de Barros se realizam sínteses de saberes estéticos que concorrem na obtenção da objetividade comunicativa pela qual o evento se repõe, ao se recriar como bem diversional diferenciado nas trocas públicas de sentido.

\section{A TÉCNICA CARNAVALESCA DO LUDIBRIO APLICADA AO ARTEFATO ALEGÓRICO}

Como observa Bourdieu (I999: 229-238), a possibilidade de se fazer herdeiro é constituída na disposição prática de ser, agir e pensar expressa por alguém no percurso realizado nos posicionamentos mesmos que ocupa no espaço social, isto em decorrência da herança da qual se faz portador e merecedor. 
Igualmente parece ser verossímil conceber que o prolongamento da hereditariedade estrutural, condicionando destinos sociais, está implicado à historicidade mundana dos trajetos de vida. Ou seja, o legatário e sua conversão em herdeiro são indissociáveis das circunstâncias nas quais saberes biológicos e histórico-culturais se ajustam no movimento de coalescências e diluições das sínteses entre interações intersubjetivas e instituições na montagem de unidades psíquicas. ${ }^{4}$ Nesse sentido, o vínculo de linhagem entre Joãosinho Trinta e Paulo Barros, aliado ao tipo de transmissão intergeracional dos saberes/fazeres e dos modos de reconhecimento da vocação e do talento do noviço pelo mestre já consagrado, dá relevo a certo padrão de regulação da formação no ofício de carnavalesco próximo àquele das guildas medievais. Algo assim é ressaltado pelos próprios profissionais, e muitos pesquisadores têm se ocupado em objetivar os trâmites e instâncias em que se modelam essas subjetividades artísticas no transcorrer de décadas nos ateliers em meio ao círculo anual de produção da materialidade carnavalesca apresentada no acontecimento anual do ritual festivo competitivo dos desfiles (Santos, 2006; Guimarães, I990).

Sem negligenciar a importância desse aspecto, para os propósitos deste artigo a tônica se volta para os saberes transmitidos na realização da forma significante estética particular ao ofício de carnavalesco; isto quer dizer que a dimensão ritual e a temática mesma do carnaval permanecerão como um pano de fundo do qual não trataremos. Por forma significante entendemos a classificação/nomeação que distingue como estética as combinações de formas, cores, texturas (Bell, 2009: 23) em observância de hábitos mentais com referência a um quadro de saberes compartilhado no plano público e, igualmente, acomodado nas convicções com as quais pessoas diversas relacionam produtores e produtos como artísticos. Por saber definimos um insumo simbólico em que se veiculam conhecimentos de base genética e/ou sociocultural capazes de, ao modelar e modular pulsões humanas, fomentar a regulação e a autorregulação de condutas (Elias, I998a: I39).5 Retomo, uma vez mais, os termos com os quais Marília Gabriela apresentou Paulo Barros. Ela referiu-se ao perfil de alguém capaz de conjuminar "inovação" e "criatividade" em suas atitudes, relacionando ousadia e irreverência, mas obediente à finalidade de suscitar surpresas e promover polêmicas. Ora, podemos concluir que os saberes transmitidos no curso intergeracional entre os realizadores da arte do carnaval estão conglomerados pela potência de gerar efeitos nos que estão localizados como público-plateias de suas intervenções, sejam os leigos anônimos, seja a crítica especializada. Fazendo recurso à ideia de conhecimento pelo corpo ${ }^{6}$ (Bourdieu, 200I: I57-I98; 2002: I7I), propomos estar no dueto entre a sedimentação corporal e a performatização desses saberes na atuação dos carnavalescos a chave para analisar a definição do ponto de vista prevalecente no espaço social do carnaval-espetáculo. 
Espaço este a ser continuamente ocupado, no instante em que estes saberes habilitam os carnavalescos a darem concretude à classificação que os nomeia na execução mesma de modalidades de expressão. São estas que os fazem reconhecíveis na medida em que eles sabem conciliar o que lhes parece o cálculo espontâneo na elaboração de formas artísticas com o domínio de expectativas do entorno sistêmico frente ao qual devem lidar com a objetividade da situação comunicativa, o que lhes impõe manter os limites da diferenciação entre a raridade do que apresentam e a banalidade da plateia.

Em outra oportunidade (Farias, 20I2), propusemos estar articulada à ideia de luxo, na estética dos desfiles das escolas de samba, uma atribuição de raridade conferida ao extraordinário de contemplar um belo passageiro, sabidamente artificial, pois resultante da intervenção humana hábil em concretizar a ilusão com a aquiescência dos sentidos corpóreos da plateia, deixando entrever, deste modo, a cumplicidade na potência do falso entre o querer iludir e o deixar-se enganar. Portanto, tomando de empréstimo a sentença de Gombrich (I995: 2I4), a expectativa gera ilusão pela projeção direcionada ao material simbólico mobilizado na montagem dos artefatos de efeitos de luzes, formas e cores apresentados nos desfiles. Aquelas propriedades aliam-se à engenhosidade, como competência eficaz do artista em saber manipular ingredientes, visando obter adesão da assistência, com a disponibilidade desta última em se deixar conduzir mediante os efeitos suscitados nos seus sentidos pelo próprio engenho ludibriante. O campo semântico da palavra ludibriar, sabemos, envolve as ideias de troçar, zombar na medida mesma em que contracena com significados à maneira de evadir, iludir e enganar, ou seja, tanto o ato de fuga quanto aquele do fingimento, seja do ponto de vista daquele que parece acreditar em algo que sabe não ser verdade, seja do agente que move recursos para gerar a sensação de verdade. Denominaremos esse saber intrínseco à arte do carnavalesco de "técnica do ludibrio". Utilizamos a noção de técnica relacionada à visão instrumental que molda as coisas em objetos a favor dos propósitos de um agente. Nesse caso em específico, a técnica envolve escolhas, mas estas requerem observadores comungando em torno da busca de objetos que lhes proporcionam sensações de beleza. Portanto, se os objetos artísticos relativos a esse saber são cosmos específicos, ao mesmo tempo, neles se prima pelo retorno a esquemas de percepção, estando subordinados à condição de instrumento comprometido com a recompensa imediata da sensação do belo palpável no empiricamente apreendido.?

A substância dessa raridade estética nos parece ser alvo de interesse analítico, porque a entendemos contracenando com a problemática acerca do ajuste da evocação do belo-bem artístico com a técnica como requisito à canalização da atenção dos sentidos corpóreos no acontecimento revestido do carisma estético. Este fator conta com decisiva relevância na configuração atual da cultura em que se inscreve o evento carnavalesco carioca, pela me- 
diação institucional do entretenimento, domínio em que a proliferação de imagens responde ao imperativo da vibração emocional da surpresa e se impõe à produção cultural (Lipovetsky \& Serroy, 2009: I0o). Visando situar a participação do saber próprio da arte do carnavalesco nesse concerto, parece-nos adequado ponderar que o saber que circula entre as gerações de carnavalescos se revela uma faceta do modo como se realiza a diferenciação sistêmica do entretenimento. Isso ocorre no momento em que nele se articula características do raciocínio mágico, tais como a faculdade de proceder por adições em busca de efeitos, com aquelas da racionalidade empenhada em domar o acaso mediante a previsibilidade e o cálculo na confecção de imagens inebriantes a fim de promover o êxtase numa situação de diversão. Assim, o saber e a prática que incita coparticipam da dinâmica pela qual se definem as margens para a autonomia relativa de as imagens aderirem com relevo à experiência contemporânea.

A premissa acima reclama historiar, ainda que de maneira sumária, o saber do carnavalesco e sua circulação intergeracional no compasso da institucionalização do desfile de carnaval-espetáculo.

De acordo com a historiografia que se ocupa do tema do carnaval no Rio de Janeiro, ao longo da segunda metade do século XIX e princípio do século XX, o formato majestoso de desfile de préstitos ajudou a consagrar o dia de apresentação das grandes sociedades (que hoje é protagonizado pelas escolas de samba), a Terça-Feira Gorda, como o momento mais esperado da folia carioca. O fator primordial para esta escalada de sucesso popular, logo que outras sociedades carnavalescas surgem, é a decisão de estabelecer a competição entre as entidades, contando com o apoio dos grandes jornais e círculos de comerciantes (Moraes, I958). O ímpeto dos seus organizadores em reafirmar o caráter "civilizado" das grandes sociedades atuou na consagração do evento na folia urbana. Procurou-se aliar crítica política e luxo (brilhos, mulheres e suntuosidade) (Cunha, 200I).

A introdução do concurso potencializou a força integradora e diferenciadora desse modelo de participação carnavalesca. Antes, porém, o torneio entre as diversas procissões inscreveu a performance na folia em um conjunto de combinações morfológicas definidas e asseguradas por regras escritas, constituindo uma forma, cuja incidência sobre a prática concreta se torna notória no ato de avaliá-la, exatamente pelo caráter público da exposição, precipitando a uniformização dos comportamentos postos diante das plateias. Isto de acordo com um arranjo social no qual a codificação escrita e a normatização judiciária impõem-se aos costumes e à transmissão oral, à medida que ocorre a monopolização estatal crescente do uso da força física e simbólica; monopólio manifesto, entre outros planos, na regulação contratual jurídica das diferenças entre os agentes sociais. Suscitava-se, desse modo, a rotinização de uma malha de ações coordenadas, visando à obtenção do 
resultado esperado, passando a demandar a estruturação formal, seja burocrática, seja artística das entidades, tendo em vista a finalidade de fazê-las bem articuladas e funcionalmente eficientes. Cada setor deveria, portanto, agir com autonomia, porém sincronizado aos demais, já que a harmonia do conjunto depende dessa arquitetura. Por sua vez, tal princípio implica a centralização das funções de comando organizacional e artístico.

É preciso levar em conta a tensão inerente a esse processo de constituição dos protocolos do gênero lúdico-artístico desfile de carnaval-espetáculo (Farias, 20I3), porque o desfile consiste em uma experiência de expressão-comunicação para a qual é imprescindível observar o tempo e o lugar oportunos à feitura dos lances de significação. Logo, o acaso é algo suposto na racionalização do ato, pois a ponderada moderação é o recurso procedimental necessário à definição extensiva de uma linha de conduta afirmada na continuidade de um sentido de agir reiterado nas tomadas de posição dos agentes que o realizam em suas respectivas coreografias de atos. Logo, a realidade do concurso como experiência desloca o controle do tempo dos pilares de uma tradição, da reiteração do costume como convenção naturalizada, para uma situação precária ancorada no presente, exigindo saídas reflexivas para domar as intervenções circunstanciais. Enfim, a forma não corresponde ao absoluto, pois requer a busca constante de atualizações, desde aí, de diferenciação social do evento mesmo. O elemento novidade detém, então, a primazia e integra a forma do gênero desfile de carnaval-espetáculo, ${ }^{8}$ tanto estética quanto organizacional. Tal atitude individualiza as entidades, ao colocá-las distintas do público. Desse modo, a questão da identificação entre um e outro polo tornou-se o problema nevrálgico a ser enfrentado nas apresentações pelas instituições carnavalescas, e a prática competitiva internaliza a mesma tensão, em razão da flexibilidade suposta na renovação reflexiva das normas na legislação dos concursos. A situação sugere o peso adquirido por atuações mediadoras capazes de apaziguar a defasagem existente entre a produção e fruição/consumo. Afinal, urge promover efeitos fortes o suficiente que sensibilizem a plateia, observando sobremaneira aquilo compreendido como "belo" no contexto festivo do carnaval.

Abre-se, assim, o espaço para que um contingente de profissionais ligados ao universo do teatro e das artes plásticas entre na festa e contribua para a rotinização do circuito de elaboração da folia. Pessoal que daí em diante seria imprescindível às concepção e montagem das cenografias móveis e postas, no dorso de carros, a deslizar pelas ruas durante o cortejo, sujeitas ao crivo do julgador do quesito "maquinaria" - aquele incumbido de avaliar a "engenhosidade" e a "beleza" dos cenários ambulantes montados. A alegoria carnavalesca torna-se o núcleo do carnaval-espetáculo.

Se alegoria carnavalesca consiste no empréstimo feito junto às suas congêneres medievais e barrocas, escapa-lhe o caráter esotérico dessas últi- 
mas, afinal não compartilha do mesmo edifício cultural definido pela narrativa cristã. Aderindo à proposição de Cavalcanti (I994), a centralidade se dá nos rastros da sua escalada como elemento visual em meio à desintegração das memórias comunitárias e da experiência coletiva, marcante do desenvolvimento da grande cidade. Ao mesmo tempo, sua afirmação refrata a definição de novos operadores simbólicos e semióticos galvanizando as sensibilidades no contexto urbano. Assim a configuração de um público anônimo tem contrapartida na força comunicacional obtida pela alegoria (como elemento visual), exatamente porque concatena pedaços simbólicos consagrados do mundo e concorre no, ainda que efêmero, sentido de proporcionar um elo consensual junto à heterogeneidade dos que a contemplam no teatro aberto da festa no âmbito metropolitano.

Advém daí o destaque obtido por essa mão de obra de artistas visuais inserida nas engrenagens de preparação dos desfiles-espetáculos. Sua origem está ligada ao desenvolvimento da atividade teatral no Brasil, notadamente após a vinda da Família Real, no início do século XIX (Farias, 2013: 219-320). Muitos desses profissionais incorporaram, via Lisboa, técnicas oriundas das transformações vivenciadas na arte de representar e das transformações na produção e nos usos populares desta, quando da passagem de um universo campesino para o urbano, na Europa (Martín-Barbero, I987: I26-I27). Desde a França, espalharam-se os teatros de divertimentos, numa mistura entre a comédia, o melodrama e a opereta, desdobramentos dos espetáculos das feiras e os circenses, que redundou nos vaudevilles, music hall, nos espetáculos dos cabarés e cassinos franceses e, posteriormente, dos norte-americanos, e nas revistas musicais. Mais tarde, também da França, foram disseminados os chamados espetáculos de "fantasia", nos quais texto e impacto visual se uniam, no formato de bailados, apoteose, "apelos mitológicos, históricos e alusões a outros povos e cenarizações exóticas" (Ruiz, I988: I2I). Prevalecia, antes, uma estética sobremaneira visual e de muito movimento cênico.

A atmosfera de glamour desses espetáculos realiza-se na busca permanente de artifícios e estratagemas capazes de sensibilizar as plateias, maravilhando-as pelo investimento na anatomia dos objetos da visão. Inserem-se, desse modo, os esplendores e altas golas emplumadas, as lantejoulas brilhantes, as roupas cavadas e insinuantes de corpos femininos dispostos aos rebolados, com braços sempre abertos e lábios sorridentes, no convite à alegria. A música ligeira é inserida complementando a visualidade. As escadarias em forma de cachoeiras de luz ou os "queijos" (pequenos tablados onde se colocam as vedetes) formam, com os espelhos e os refletores, as cenarizações de deslumbre, valorizadas pelas pluricromatizações vibrantes. Este é o modelo cênico mediado para o interior do carnaval citadino, por aqueles envolvidos com esse universo da produção do encanto, e que deitará profundas raízes em toda a sua posterior existência. O sentido do fulgor e do ilusionismo, como 
manifestação da beleza, interioriza-se na realização das práticas como um sistema de disposições, configurando-se, seja no plano das técnicas, seja no dos valores. Ainda, tendo na conquista do prestígio seu núcleo aglutinador, quando se atinge o objetivo de estabelecer consensos a respeito do esplendor proporcionado pela passagem das agremiações e, assim, reiterando a vocação de encanto do evento.

Nesse sentido, organiza-se a extensão participativa das instituições no festejo, conformando a regra fundadora do gênero desfile carnaval-espetáculo, isto é, produzir impacto nos olhos de quem anonimamente contempla o cortejo carnavalesco. Nesse momento, desponta o especialista simbólico decisivo à institucionalização do carnaval-espetáculo: o técnico. Como observa Helenise Guimarães, o conúbio entre tais profissionais e o financiamento oriundo dos comerciantes e profissionais liberais facultou às grandes sociedades tornarem- se espécie de "laboratórios" (Guimarães, I990), dentro dos quais a arte baseada na técnica do ludibrio cumpre decisivo papel na formação do gênero desfile voltado às amplas plateias, ou sendo mais exato, o desfile-espetáculo, posteriormente estendido, mas reelaborado, pelos ranchos e escolas de samba.

Anos mais tarde, em I932, o jornal Mundo Sportivo noticiou uma nova atração na folia carioca: o primeiro concurso entre as escolas de samba ocorrido na região da Praça XI, no centro do Rio de Janeiro. Promotor do evento, o veículo alardeou o caráter exótico e inusitado do acontecimento. Afinal, dos morros e subúrbios desceria uma gente dançando e cantando em um ato desinteressado de êxtase órfico, ritmado pelo concerto de instrumentos musicais, muitos dos quais seriam igualmente sedutores por sua rusticidade quase "primitiva". Um cálido coro efervescido pela percussão musical do samba. Essa imagem dionisíaca percorre o curso da história do desfile das escolas de samba, sendo parte fundamental da sua narrativa mítica. Como todo mito, trata-se de uma fala capaz de se desvelar no movimento mesmo em que esfuma sentidos e, com isso, ultrapassa incongruências internas à própria historicidade do evento carnavalesco e das agremiações que o compõem.

Não se pode esquecer que as escolas de samba fazem parte, enquanto instituições civis recreativas, das táticas que visam concretizar a participação no espaço público urbano carioca por parte de grupos subalternos, pobres, com forte mácula étnico-racial e cuja intimidade fora alvo de continuada vigilância tanto pelos aparelhos repressores do Estado republicano quanto pelos mecanismos ideológicos e civilizatórios burgueses, em um período ainda próximo ao fim da escravidão (Lima \& Lima, I99I). Portanto, a adoção do modelo desfile de carnaval-espetáculo, por volta dos anos de I920, sob a inspiração dos já consagrados ranchos e grandes sociedades, pelas lideranças compostas pelos sambistas, condensa um sinuoso trajeto de expansão metropolitana. Da forma dramatúrgica e plástico-visual das passeatas se fez a 
contrapartida lúdico-estética de conflitos e acomodamentos, inserções seletivas e exclusões relacionadas às maneiras de adequar o binômio entre civilidade e polimento estético na aparição pública dos mesmos grupos durante a festa (Fernandes, 200I: I44; Turano, 20II: I33-I42).

No decorrer dos anos em que as escolas depuraram esse estilo, exposto primeiro na Praça XI, em seguida na Avenida Rio Branco e depois na Avenida Presidente Vargas, cada vez mais apinhada por multidões de espectadores acomodadas em arquibancadas e camarotes vendidos, até a conquista do espaço definitivo da Passarela do Samba - mais conhecido como "Sambódromo" -, ganhou dimensões o concerto entre ordem e descontração festiva. Ao longo desse período se consolidou o deslocamento simetricamente retilíneo de magotes ordenados em alas e entre ícones alegóricos, organizados na forma operística e rítmico-coreográfica. E, nesse movimento, o conjunto lúdico-artístico se integrou ao zoneamento de lazer e diversão na cidade, ao ser nacionalizado, estendendo-se para dimensões transclassistas e transculturais, adquirindo o status de objeto expressivo-comunicacional participante do tráfego transnacional de imagens, ancorado na ecologia das mídias audiovisuais eletrônicas e no circuito internacional do turismo (Farias, 2006: 182-238).

Em meio à formação e ampliação da gama de serviços artesanais internos às divisões funcionais no sistema do carnaval-espetáculo (Feijó \& Nazareth, 20II), o aumento na ingerência da função/posição do carnavalesco acompanha a afirmação do status de intelectual desse ofício. A partir dos anos de I9960, os carnavalescos concentram as atividades de propor a trama literária e dramatúrgica que justifica o cortejo, o enredo, estando sob sua responsabilidade a materialidade plástico-visual (alegorias, adereços e fantasias). No interior dessa divisão técnica dos trabalhos, o fazer do carnavalesco se impõe ante prestadores de serviços, como escultores, vidraceiros, marceneiros, costureiras, bordadeiras, ferreiros, decoradores, entre outros artífices (Farias, 20I3). É em meio a essa ampliação da engrenagem produtiva que se intensifica a dinâmica de estilização que paulatinamente forja o padrão de superespectáculo do evento. Mas é importante ressaltar estar essa mesma dinâmica à mercê da transmissão intergeracional do saber fazer da arte do carnavalesco.

É nessas trocas entre gerações que se realiza a consolidação da forma como as escolas de samba tomam a passarela com ambientações que devem primar por serem capazes atrair as audiências (direta ou próxima do vídeo), no tempo efêmero definido para a sua exibição. As escolas de samba procuram encher a moldura da pista, e consequentemente também da tela televisiva, com elementos dotados de suficientes informações acessíveis, que igualmente sejam hábeis em disponibilizar efeitos visuais. A novidade assume desse modo o lugar de imperativo: é uma presença que iguala todas as concorrentes, formando determinado imaginário a respeito da festa-espetáculo, atre- 
lando expectativas e funcionando como mecanismo de pressão, mas não consiste numa pressão em favor da ruptura e, sim, num apelo à variação de acordo com outros "textos" conhecidos pela audiência.

O carro alegórico catalisa esse primado da novidade. Ano a ano deve superar-se não só em proporção física, mas no impacto que seja capaz de provocar mediante figurações que facultem força persuasiva à aparência. Isto graças ao recurso a um manancial de caracteres da memória de signos de origens as mais diversas, mas inseridos na memória da cultura do audiovisual de alcance mundial. O procedimento de selecionar nesse repertório está em sintonia com a premissa de incitar o reconhecimento, no espectador, das informações arroladas. Para tanto, outro mecanismo comparece na confecção da imagem, a saber, a exacerbação dos sinais visíveis, com a instrumentação das cores e dos artifícios de iluminação. Tais sinais são disparados na direção dos olhos da plateia. O empreendimento comunicativo-expressional é caracterizado, portanto, como uma estratégica estética cujo exercício de espiritualizar a matéria cenográfica recorre sempre mais aos recursos de luz e cor com o propósito de atuar sobre as instâncias psicossensoriais de quem assiste às passeatas. Poderíamos sugerir o propósito de atrelar o olhar às formas móveis, efetivando um elo identitário na imediatez da exposição, disposta na contrapartida da ausência de profundidade étnico-histórica. O já referido dado mágico comparece na atitude de constranger até a composição de uma totalidade entre os cenários e o espectador, no instante em que as formas e os conteúdos expostos concretizam valores condizentes com expectativas, equalizando e reiterando as posições mútuas de audiência e espetáculo. A existência de momentâneo encantamento, logo, está estruturalmente articulada à demarcação dos limites do relacionamento entre plateia e escolas de samba.

Como nos referimos antes, em vista dessas delimitações, a alegoria carnavalesca guarda afinidades com a alegoria barroca, mediante a tônica posta na cenarização e no verossimilhante (Argan, 2004: 33-39). E, também, quanto ao dilaceramento do real, ao excesso, à instabilidade. Segundo Cavalcanti (I994: I68), a figuração alegórica das escolas condiz com o processo social de elaboração dos desfiles anuais por não existir um sentido imanente de unidade (típico da arte simbólica), mas trocas agonísticas entre diferenças socioculturais mediadas na forma coletiva da festa e a sua produção e participação. Ainda, a autora argumenta que se encontra na estética alegórica o lócus de interação das experiências fragmentadas na cidade-metrópole.

Infere Walter Benjamin (I984), entretanto, que na percepção barroca a ruína é entronizada como concepção de mundo e, ao mesmo tempo, diz respeito ao instante fragmentário que interrompe a repetição do mesmo na história, ou seja, do mito do progresso moderno. Já em se tratando do desfile de carnaval-espetáculo, a alegoria corresponde a um artefato mobilizado visando à comunicação eficiente, isto é, a busca da univocidade do sentido 
de diversão por meio do dado sintético do carro alegórico. E a busca está articulada em um sistema cenográfico tributário das conquistas da tecnologia e da especialização técnica das atividades, com o objetivo de provocar significações, no momento de decodificação das formas. Objetiva-se provocar a identificação empática de quem contempla. O recurso reflexivo à estética barroca do excesso cumpre o propósito funcional de estabelecer uma totalidade passageira cuja dimensão ocupa e supera todo o olhar do espectador. Bombardeia-o, como assinalado, com informações que se multiplicam, sistematicamente dispostas em imagens visuais, mas que favoreçam o entendimento fácil por parte de quem assiste9. A estratégia executada visa evitar a apatia do expectador e consiste em transformar a heterogeneidade em unidade, isto em um conjunto com a homogeneidade rítmico-musical dada pelo canto uníssono calcado no andamento unitário da bateria, mas dando ênfase à proliferação de detalhes, no movimento da ambiência cenográfica.

\section{O DIALETO ESTÉTICO E A EVOCAÇÃO dO FASCínIO DAS IMAGENS}

No caudal das nossas conversas com carnavalescos e do acesso à literatura especializada, notamos que, se a temática da intriga contada é o que determina o planejamento do espetáculo audiovisual deambulante, o próprio tema deve ser obediente ao primado de impactar os olhares da audiência. Nesse sentido, o conjunto indumentário, sobretudo o cenográfico, para além de complementar o enredo, ocupa posição-chave na relação com outros aspectos que compõem a ambiência móvel do carnaval-espetáculo. ${ }^{\text {Io }}$ Por isso, as escolhas dos enredos estão condicionadas à potencialidade de produzir diversas imagens, nas quais estejam presentes as sugestões de sentimentos, sem abrir mão de provocar surpresas esperadas.

No item anterior, vimos como a prioridade posta na sucessão das imagens visuais, tendo por suporte o artefato da alegoria carnavalesca, em sua complexidade constitutiva, compreende a tentativa de reduzir a heterogeneidade da plateia mediante o emprego de detalhes em profusão de acordo com os ditames estéticos de um neobarroquismo. À medida que fizemos a escuta das fontes orais, mas também consultamos documentos e registros em fotografia e vídeo dos desfiles nos últimos cinquenta anos, evidenciou-se a contínua e crescente participação desses materiais nas diferentes procissões das escolas de samba, seja aquelas que integram a divisão principal, seja as que integram os grupos inferiores do concurso anual. De uma média de três dessas peças usadas nos desfiles das décadas de I960, elas irão saltar para mais de oito por volta de I980. Suas proporções em termos de largura e comprimento também se estendem na contrapartida do cada vez maior número de andares ostentados pelos carros alegóricos. As peças saíram de uma média de 2,5 metros de altura por 5 metros de largura e comprimento, chegando à 
média de 20 a 25 metros de altura por dez metros de largura e 60 metros de comprimento. No mesmo compasso se amplia o detalhamento icônico, agregando esculturas, pinturas de arte e mais adereçamentos à base de materiais variados - látex, acrílicos, vidros, espelhos, vime, madeira, empanamentos e outros -, facultando volumes plásticos de maior envergadura e, logo, visibilidade.

A ascendência do comando estético do carnavalesco se deu no aumento sempre mais complexo da rede de fazeres do fabrico das alegorias. Portanto, embora os carros alegóricos e as fantasias compreendam partes do protocolo do ritual festivo-competitivo, ambos foram alterados em seus respectivos significados pela intervenção do ofício do carnavalesco, no decorrer desse período. Nesse sentido, ainda que consista em uma arte coletiva (Cavalcanti, I999: 45-54), os rumos tomados pela elaboração dos elementos alegóricos não somente fizeram prosperar uma diferenciação funcional dos fazeres, em especial proporcionaram a individualização de algumas posições cujas atividades ganharam relevância em relação às demais em virtude de apresentarem alternativas de preenchimento dos espaços a serem ocupados nas passeatas. Lembrando que os desfiles cada vez mais foram redimensionados pelos olhares dispostos em andaimes altos de arquibancadas (cujo ápice dista 60 metros do chão) ou mediados pelas lentes televisuais. A conexão estético-sistêmica entre alegoria e ofício carnavalesco correspondeu à principal entre as alternativas adotadas e consagradas. A composição de uma espécie de star system formado por alguns nomes integrantes do elenco de carnavalescos decorreu, portanto, do enlace entre dois aspectos. De um lado, as vicissitudes históricas, nas quais foram estruturadas personalidades reconhecidas e autoidentificadas pelo gênio da criação artística. De outro, o entrosamento da transmissão intergeracional de saberes técnicos com arrojo nas soluções intencionalmente idealizadas tanto para conceber como para dispor a materialidade visual nos desfiles evocando imagens aptas a fascinar.

A partir de agora, justamente, temos por meta evidenciar esse arranjo, tornando a olhar o legado de saberes entre Joãosinho Trinta e Paulo Barros. Não nos interessam as respectivas sociobiografias de um e outro agente, mas, sim, como o dialeto estético próprio a cada um se comunica entre si e se deixa apreender nos modos de concretização dos objetos artísticos - no caso, visuais -, por eles concebidos. Nesse sentido, aqui, a ideia de dialeto estético se refere à codificação das idiossincrasias individuais, revelando o ajuste das intenções com decisões tomadas nos cruzamentos de reportórios sedimentados de geração a geração de conhecimentos e pressões manifestas na atualização dessa mesma herança de saberes (Calabrese, I987: p.I09). Algo assim equaliza os traços de originalidade própria a uma linha de agenciamento com o nível de redundância que inscreve essa mesma linha nos limites de um modo de fazer artístico. Aceitando a sugestão de Baxandall (2006: 80-86), para os propósitos deste texto, a ideia de intenção está referida ao objeto artístico 
em suas circunstâncias, nas quais se define determinado interesse estético pautando escolhas. Portanto, o interesse estético é relativo às diretrizes de procedimentos especificando certo problema a ser elucidado. Assim, envolvendo os meios cognitivos e técnicos de realização, quando ambos já estão sintetizados em hábitos visuais vinculados a percursos mútuos de agentes e instituições no escopo de experiências sócio-históricas de maior abrangência (Baxandall, I991: 37-I82).

A introdução dos temas oníricos no carnaval das escolas de samba do Rio de Janeiro respondeu ao problema de fornecer uma diversidade de imagens visuais na mesma proporção em que o aumento das alegorias alterava a diagramação dos desfiles, compactando a sucessão das alas de componentes. E, ao mesmo tempo, ia a favor de uma percepção cada vez mais verticalizada das apresentações. Mais tarde, o reforço da visualidade se aprofundou com o recurso cênico ilusionista do emprego intensivo de placas de espelhos na decoração dos carros alegóricos. Depois, acrescentou-se um novo aliado na mesma direção: os canhões de luz artificial (alimentados por motores a diesel). A autoria dessa triangulação é atribuída a Joãosinho Trinta. As intervenções desse agente no protocolo da cerimônia das escolas de samba reiteram o modo como séries de retomadas e conversões de saberes teceram, na matriz institucional e estética constituída pelo Grupo do Salgueiro, durante os anos de I960, a arte do carnavalesco (Farias, 20I2). Mas sua participação, ao mesmo tempo, adquire singularidade na medida em que ressalta a autoria de um conceito de desfile e de sua personalidade artística. Os enredos por ele propostos eram executados tendo por núcleo dramático o carro alegórico preenchendo "vazios" espaciais no deslocamento do cortejo, e a dinâmica da linguagem audiovisual se impunha pela primazia concedida para a dinâmica da escala cromática em uma narrativa contada à base de imagens cenográficas e indumentárias.

Em 1974 ele assume a responsabilidade de elaborar o carnaval da mesma Acadêmicos do Salgueiro e assina o enredo O rei de França na ilha da assombração. A proposta estava em narrar a invasão francesa no Maranhão do ponto de vista da imaginação do então pequeno Luiz XIV, privilegiando a imaginação fantasiosa do "rei menino". Na cenarização elaborada, após o carro abre-alas, seguido da figura de destaque da rainha Catarina de Médici, candelabros espelhados de mais de três metros de altura estavam fundidos a esguias palmeiras tropicais na materialidade laminada prateada, montada sobre tripés dispostos nas laterais da pista. No miolo desse cenário, a indumentária dos componentes de ala fundia a corte francesa e os indígenas do Novo Mundo. Recorrendo à memória oral popular, representada ali pelas alas de baianas vestidas de "pretas-velhas", abriu-se o setor dramático Cortejo das assombrações, materializando lendas brasileiras sobre o fantástico. De acordo com a descrição do roteiro do enredo, nas noites de lua cheia, na Praia dos 
Lençóis, na cidade de São Luís, do mar saíam "seres estranhos" para enfeitar com algas prateadas o pódio alegórico composto pela figura exuberante de um enorme Touro Negro. Acalmadas as águas, ainda segundo a narrativa do enredo, esses seres e o próprio touro se tornavam gente de outro tempo que compunha o séquito do rei português Dom Sebastião, misteriosamente desaparecido durante a batalha de Alcacer-Quibir. Mantendo o uso dos tons branco e prata, a fim de atingir o efeito surrealista, as cenas seguintes focaram outras lendas até culminar na passagem da carruagem puxada por três mulas sem cabeças. A alegoria à base de acrílico prateado com tons vermelhos estava cercada por escravos puxando correntes para ilustrar a tragédia da violenta fidalga Nhã Jança, cuja alma vagueia imersa em labaredas. No avanço do cortejo, transformadas pelas chamas, as joias e demais riquezas dessa personagem se tornam azulejos portugueses e pingos d'água se convertem numa enorme alegoria da Serpente de prata (Gomes \& Vilhares, 2008: 59-69).

Campeão já na estreia no oficio de carnavalesco, para o ano seguinte o enredo assinado por João Trinta propõe Os segredos das minas do rei Salomão. A proposta era de outra viagem imaginária partindo do Oriente Médio até a Amazônia pré-colonial para desvendar os mistérios que envolveriam o poder e o prestígio do lendário monarca. Mas o desfile foi iniciado pelas sucessivas visitas que as respectivas rainhas e princesas da Etiópia, Egito, Babilônia, Assíria, Pérsia, Índia e Sião faziam ao velho Salomão visando obter, em vão, informações sobre as suas minas, para isto oferecendo-lhe agrados e presentes, como o cortejo da Rainha de Sabá, em sua tenda, cercada de negros de olhos verdes. De acordo com a descrição do enredo, apenas o Rei de Hiram da Fenícia sabia chegar às Terras de Ofir e fora ele quem conduziu a epopeia ilustrada por pirâmides e esfinges egípcias, bigas puxadas por cavalos, povos, animais e a flora do Saara e da África negra e tantas outras cenas, no melhor estilo dos épicos do cinema de Hollywood, dirigido por Cecil B. DeMille. O fechamento da apresentação se deu com o Ritual de consagração das pedras verdes, realizado pelas guerreiras amazonas no lago de Iaciuaruara e, ainda sob o clarão lunar, elas se entregavam durante toda noite aos prazeres, nas núpcias celebradas com os fenícios (Gomes \& Vilhares, 2008: 68-69).

No carnaval de i980, agora no comando da escola de samba Beija-Flor, uma vez mais convida a plateia para outra viagem imaginária, desta vez a Viagem ao País das Maravilhas, a partir de uma comissão de frente formada por soldadinhos de chumbo, abrindo um cortejo compatível aos musicais de Walt Disney. Na apresentação, um alto carro abre-alas, todo em tom prata e decorado por espelhos, portava um carrossel onde crianças, sobre cavalos alados, estavam encimadas por fadas-madrinhas em topless. Fazia-se seguir de coloridas e enormes esculturas de animais falantes; compondo uma mesma peça cenográfica, Dona Baratinha e a figura imensa do Cozinheiro e seu efervescente caldeirão, onde estava mergulhado Dom Ratão; os personagens das Mil e 
uma noites; a Carruagem abóbora com Cinderela. Entre outras imagens infantis, se seguiram: o cenário mesclando naipes de prata, branco, dourado e azul abrigando Branca de Neve e os sete anões, o carro alegórico do Jogo de xadrez, da bruxa. Uma sucessão de imagens, até surgir o sorriso gigantesco de um palhaço colorido, representando o Sol da meia-noite, o próprio carnaval (Gomes \& Vilhares, 2008: 96-IOI). No ano seguinte (I98I), é o mesmo carnaval assumido como tema, ao ser elevado à condição de Oitava maravilha do mundo. Antecederam-lhe, na homenagem, alegorias ilustrando outras maravilhas - o Jardim Suspenso da Babilônia (com chafariz chorando jatos de água), as $\mathrm{Mu}$ ralhas da China, o Colosso de Rhodes, o Templo de Diana, a Estátua de Zeus, mais uma vez as Pirâmides do Egito, o Farol de Alexandria (com spots giratórios). Só aí surgiu, repleto de prateados pompons luminosos e flores giratórias, mas ilustrado, ainda, pelos corpos seminus de mulatas, o carro alegórico decorado por pompons em plástico transparente da telúrica Oitava maravilha, o carnaval brasileiro, como, na frase do samba-enredo, "um monumento vivo e multicor [...]", prenhe de signos alusivos à sensualidade tropical (Gomes \& Vilhares, 2008: 102-I07).

Sintetizadas como soluções, as quais são paulatinamente adotadas por outros realizadores do carnaval-espetáculo até se constituírem em parte indissociável do padrão do superespectáculo dos desfiles, as intervenções que consagraram o dialeto estético de João Trinta contribuíram para elucidar problemas estético-visuais relativos à expansão das bases sociais que se manifestaram na prioridade posta às agremiações estarem à altura do protagonismo em um evento cultural prestigiado e inserido no mercado de bens simbólicos populares. Por outro lado, com o delineamento da forma de situação sociocomunicativa do desfile de carnaval-espetáculo, um leque novo de problematizações impôs-se no sentido de atualizar e consolidar a mesma forma-espetáculo por intermédio de novas mobilizações, engajando elementos os mais diversos na formulação de imagens expressivas, reforçando a natureza audiovisual desse gênero cultural de diversão.

\section{DESVENDAR O SEGREDO PARA MANTER A ILUSÃO}

Desde aí tem ocorrido o incremento na divisão técnica do trabalho na elaboração geral do ritual festivo e, assim, o reforço na complexidade das funções acirrou o recrutamento maior de quadros. Portanto, nos interessa vasculhar como as técnicas do ludibrio circulam, fomentando novas cenarizações apresentadas. Desse modo, abordaremos as materializações artísticas que Paulo Barros propôs e esteve no comando da execução, as quais resultaram no reconhecimento obtido entre os seus pares e pela crítica especializada como o herdeiro desse saber da arte do carnavalesco. Por questão dos limites deste texto, nossa atenção toma por objeto suas realizações elaboradas na esco- 
la de samba Unidos da Tijuca. A escolha se justifica pela maior permanência do agente nessa agremiação. Desse modo, nos ateremos aos trabalhos que se estendem entre 2004 e 20I2. Frisamos, ainda, que abordaremos aspectos que consideramos relevantes para o nosso argumento, logo, não temos o compromisso de descrever e analisar todo o conjunto dessas obras. ${ }^{\text {II }}$

No tocante ao plano metodológico, materialidades dizem respeito, aqui, ao engendramento mútuo entre a coisa, o saber e o sentido. Portanto, no retorno descritivo a essas materialidades, empregaremos a proposta de semiótica da cultura com a finalidade de decifrar signos detendo códigos e significações inscritos em estruturas transcendentes ao imediato do acontecimento, já que dizem respeito ao anelado composto pelo saber da codificação do gosto, mais a intencionalidade do artista e a estratificação das leituras (Calabrese, I986: 7I; Koethe, 20II: 2I). Não se trata de tomar as estruturas como fundamentos autorreferentes, mas concebemos a ideia no tocante à probabilidade de um episódio se impor a outro, mais propriamente de um comportamento humano ocorrer em detrimento de tantos outros possíveis. No caso, o comportamento é esta conduta orientada pela técnica do ludibrio, informado pelo saber da arte do carnavalesco, contracenando com a diferenciação social do gênero desfile-espetáculo.

Até o ano de 2003, Paulo Barros atuou nas escolas de samba situadas nas divisões inferiores na hierarquia do concurso em que consiste o carnaval-espetáculo no Rio de Janeiro. ${ }^{12}$ Sua passagem pela escola de samba Paraíso do Tuiuti lhe rendeu certo reconhecimento, em razão da solução de cenário retratando o quadro $O$ espantalho, do pintor Candido Portinari - homenageado pelo enredo da agremiação naquele ano: Tuiuti desfila o Brasil em telas de Portinari. Na confecção do carro alegórico, em lugar de esculturas, Barros optou por figuras humanas que permaneciam estáticas e apenas a certa altura do samba-enredo realizavam movimentos coreografados para personificar espécie de delírio no qual o pintor assiste ao balé das figuras por ele criadas (Barros, 2013: I39-I4I).

Denominadas "alegorias vivas", a solução voltou a ser empregada no ano seguinte, já no Grupo Especial, ao ser contratado pela Unidos da Tijuca. Parte do enredo $O$ sonho da criação e a criação do sonho: a arte da ciência no tempo do impossível - uma narrativa acerca da relação entre arte e ciência na história da cultura ocidental -, a fórmula cênica apareceu na alegoria Energia. Nesse carro alegórico, cuja base em preto era decorada por ícones representando grandes torres de transmissão adornadas por neons vermelhos, os figurantes fantasiados de negros frankensteins desenvolviam movimentos coordenados realizando a mensagem do acionamento de corpos pela descarga elétrica, em referência à maneira como o advento da eletricidade comoveu sensibilidades artísticas, como a de Mary Shelley. Mas o momento de maior efeito se deu quando, para encenar o mapeamento do código genético humano no carro 
alegórico DNA, compondo a pirâmide feita com espelhos e metais prateados tendo ao centro tubulações douradas, sobre elas estavam I 27 pessoas seminuas, mas revestidas de gliter em tons azuis metálicos, movimentando-se nos gestos sincronizados simulando a transmissão do código genético humano (Barros, 20I3: I4I-I43). O impacto do artefato alegórico arrancou acalorados aplausos da plateia, conquistou elogios da crítica e contribuiu para levar a escola da Tijuca à segunda colocação no resultado final da disputa. ${ }^{\mathrm{I3}}$

Em 2005, já aguardado com muita expectativa pela audiência do evento, expectativa alimentada pela repercussão do seu trabalho na mídia e na impressa, onde foi incensado como promessa de criatividade e renovação, ${ }^{14}$ Barros se inspirou no The dictionary of imaginary places (Manguel \& Guadalupi, I987) e bolou o enredo Entrou por um lado, saiu pelo outro, Quem quiser que invente outro... O fio condutor da dimensão plástico-visual da apresentação se manteve fiel, desde o início, à natureza imaginativa do tema-enredo, em suas evocações do onírico e do fantástico motivadas pela ocasião carnavalesca e sua inspiração nas "aventuras da ilusão". Paulo Barros, nesse ano, evidenciou sua prerrogativa de que "não deveria ser preciso um manual de instruções" para a plateia entender as alegorias. Propôs, então, os "carros-conceito" visando realizar peças que facilitassem a leitura, evitando para isso a multiplicação de informações visuais. Ele tomou de empréstimo a técnica do assemblage, pela qual materiais são descontextualizados de seus usos cotidianos para serem dispostos na ambiência cênica (Barros, 2013: 74).

Assim, cercada por altos adereços brancos com detalhes em prata, estilizando moinhos de vento, enredada nos delírios intrépidos de D. Quixote para salvar Dulcineia, contando com o auxílio de Sancho Pança, a comissão de frente era composta de personagens referentes aos lugares a serem focalizados: País das maravilhas, Shangrilá, Eldorado, Castelo do Drácula, Atlântida, Sítio do pica-pau amarelo, Terra do Nunca, Planeta dos macacos, Olimpo, Céu e inferno, entre outros. Seguiu-se o carro abre-alas: com mais de dez metros de extensão cuja altura do andar superior chegava a sete metros, um enorme pavão branco tendo a cauda aberta em leque formada por centenas de pessoas vestidas em malhas brancas realizando, outra vez, movimentos coordenados que revezavam, às mãos, pequenos adereços coloridos de acordo com as passagens do samba enredo. A utilização de milhares de pequenas esferas de isopor para decorar o carro alegórico atendia o propósito de simular a dinâmica neurológica pela qual a mente dispõe as pessoas a aventuras fantasiosas. Espécie de instalação artística móvel, a alegoria tomou de empréstimo o conceito de mobilização expressiva de massas humanas que remete a espetáculos públicos ou aos painéis vivos utilizados em aberturas de jogos olímpicos (como em Moscou, em I980).

O mesmo conceito de expressão de massas vivas surgiu, na sequência, com uma ala multicolorida (mas com o predomínio do vermelho e preto), 
coreografada de cartas do baralho comandada pela Rainha de copas, em alusão ao livro Alice no país das maravilhas, de Lewis Carroll. Mais adiante, no encaminhamento dos setores dramáticos do enredo, núcleo à encenação do universo sombrio dos zumbis, o carro alegórico Castelo do Drácula retomava a forma piramidal, mas desta vez preenchida por trinta alaúdes em dourado e roxo, deles saindo vampiros para fazer também movimentos coordenados com as capas, cujos empanamentos acetinados internos justapostos proporcionavam o degradé de igualmente tons roxos, tendo o preto no seu inverso. Ao retornarem, faziam dançar as tampas das caixas mortuárias. Em outro setor, uma vez mais, o recurso à tematização plástica do soturno apareceu na alegoria Purgatório, para evidenciar o conceito de desordem e viscosidade interno à proposta do livro A divina comédia, de Dante Alighiere. Coberta pelo tecido preto, a alegoria tinha os contornos de uma árvore de espesso e retorcido tronco, que sustentava uma copa ostentando caveiras, a escultura branca de um anjo e vários tentáculos que desciam até envolverem, no solo, centenas de pessoas amontoadas fazendo outros movimentos coordenados. Mais próximo do fechamento do desfile, o carro alegórico Planeta dos macacos reunia elementos cenográficos para recriar a visão arquitetônica de hierarquia aristocrática e beligerância, em que os contornos majestáticos dos palácios feitos em pedra se sobrepunham, ao centro, ao uso de materiais rústicos, como a palha, a madeira e folhagens, em casebres dispostos nas laterais, todos perpassados pela luz âmbar proveniente do interior da alegoria. As máscaras portadas pelos muitos figurantes chamaram a atenção; máscaras de símios feitas sob encomenda ao estúdio da Universal Pictures, responsável pela produção cinematográfica que referenciava aquele setor do enredo. ${ }^{15}$

Este último aspecto deixa entrever uma tendência no dialeto estético de Paulo Barros: o diálogo continuado com o repertório de significados contidos nos signos que repercutem em imagens literárias, musicais e audiovisuais disponibilizadas na circulação de bens simbólicos de grande alcance de recepção, especialmente o cinema. Segundo ele mesmo afirma nos seus desfiles é como se o público fosse ao cinema. O diálogo resgata e recontextualiza essas referências imagéticas que já habitam o mundo do conhecido pelos públicos-audiências do desfile de carnaval. O procedimento não era nem isolado, nem inovador entre os carnavalescos. ${ }^{16}$ Segundo esse ponto de vista, o enredo Ouvindo tudo o que vejo, vendo tudo o que ouço, desenvolvido no desfile de 2006 , foi heurístico, porque o argumento da proposta estava em cotejar imagens sonoras e visuais propagadas por mídias diversas e como, ao serem percebidas, elas incitam a produção de outras imagens, estas de sentido fantasioso, nas pessoas.

Desse modo, vestida da irreverência genial do maestro Mozart, manipulando enormes teclas de piano, a comissão de frente conduziu o conjunto da escola e, outra vez, intitulado Resumo da ópera, o abre-alas sintetizava a proposta. Um enorme gramofone, composto por duas grandes corolas (alto- 
falantes) prateadas, cercado de pautas contendo notas musicais douradas e tendo, ao centro, um toca-discos, que, no compasso da evolução da letra do samba-enredo, tinha sua feição alterada: de um disco de vinil ostentando o nome da escola em amarelo, passava para grandes retratos de artistas ligados ao mundo da música e do cinema. Retratos manipulados pelo contingente de figurantes que, ainda, faziam 2 I movimentos coordenados referentes aos ritmos e gêneros focados no enredo, mas sob a batuta de um Mozart posto no queijo localizado no núcleo do toca-discos. ${ }^{17}$ Os setores dramáticos do enredo foram abertos pelas marchas carnavalescas. Em seguida, a cadência e a ginga do samba foram enfocadas no carro alegórico conjuminando os shows de cassino à gafieira e aos botequins. Depois, seguiram-se as tramas cinematográficas hollywoodianas em que o suspense suscita a catarse de sentimentos como o medo e o amor, culminando no carro alegórico ET - sob folhagens, envolto em névoa branca, um carrossel de bicicletas feito de placas de acrílico e tubos metálicos recria a cena da fuga do extraterrestre na atmosfera de comoção na aventura futurista tecnológica do filme de Steven Spilberg (de I98I).

O penúltimo setor dramático abordou o clima boêmio das casas noturnas de dança e música, sintetizado na alegoria Discoteca, referência ao filme Embalos de sábado à noite (1978). Encimando os dois lados da parte frontal do carro, estavam figurantes encenando totens da cultura pop: Elvis Presley e Freddie Mercury. Na parte traseira, o DJ era o próprio Mozart (na tipificação que lhe foi dada no filme homônimo de Milos Forman). No miolo, iluminados por jogos de luzes e globos de espelhos, revezavam-se contingentes dançando, respectivamente, rock, dance, soul, break. O fechamento se deu com tripés dando suporte às cruzetas coloridas para recriar a ambientação das antigas decorações que ocupavam o alto e as laterais de avenidas onde desfilavam as escolas de samba, no Rio de Janeiro. O objetivo de homenagear esta arte de rua fora o trampolim para celebrar o proprio desfile-espetáculo na alegoria Ópera do carnaval e, com isso, exaltou-se a figura do carnavalesco pela evocação dos baluartes precursores do ofício. Estilizando os contornos do Sambódromo carioca, abrigava pessoas vestidas de branco nas suas laterais, e estas faziam deslizar grandes bandeiras de cada uma das escolas de samba que protagonizam a festa audiovisual carnavalesca. ${ }^{18}$

Ainda que a Unidos da Tijuca tenha ficado apenas na sexta colocação no concurso de 2006, o sucesso de crítica e de público fez da mão de obra de Paulo Barros alvo de disputas entre as agremiações. Diante da possibilidade de maior remuneração e de atuar em uma escola de samba que, naquele momento, lhe daria maior visibilidade e recursos para materializar suas ideias, ele opta por se transferir para a Unidos do Viradouro, onde permanece por dois anos. Após uma breve passagem pela Unidos de Vila Isabel, fazendo dupla com outro carnavalesco - Alex Souza -, e cursos realizados nos estudios 
da Universal Pictures, Barros volta à Unidos da Tijuca para executar o carnaval de 20Io. Fiel à tese de que a linguagem visual do desfile deveria ser econômica em sugestões, para facilitar a apreensão do expectador, ${ }^{19}$ a proposta de É segredo era fantasiar os sentimentos despertos envolvendo episódios e personagens relacionados pela expectativa daquilo que se oculta. ${ }^{20}$ Denominada Nem tudo o que se vê é o que parece ser, a Comissão de Frente realizou truques de ilusionismos de acordo com a coreografia concebida por Priscila Mota: os figurantes revezavam vestimentas (ainda que os homens se mantivessem no modelo de fraque e cartola) e mesmo componentes, utilizando o artificio de mantos, cones e uma caixa grande feita em tecido negro - A casa do ilusionista - para esconder o trâmite da mudança.

Com cerca de 20 metros de altura, o abre-alas se referia ao mistério envolvendo o incêndio da Biblioteca de Alexandria. No carro alegórico, exibindo esculturas de deidades sob a cópia de um frontispício de marmóre, cercando uma ala de centuriões romanos em branco e dourado, a certa altura, alastrada das labaredas, a fumaça cenográfica tragava imagens dos conhecimentos que teriam sido perdidos pela humanidade. Tratava-se de mais um truque: I50 turbinas de ventiladores, embutidas na alegoria, faziam soprar verticalmente fitas de ráfia dourada simulando o fogo. Seguindo o mesmo princípio, vieram o mistério do Santo Graal, das Minas do Rei Salomão, do Cavalo de Troia e, fechando essa sequência de setores dramáticos voltados para a história antiga, o carro alegórico Os jardins suspensos da Babilônia. A alegoria era composta de colunas em azul e dourado, estava decorada por cinco mil mudas de plantas vivas e contando com um chafariz, em que os casais de figurantes encenavam jogos de sedução. E, ainda, puxado por um séquito de escravos, toda em dourado, a tumba mortuária onde estaria enterrada Cleóprata. Então foi apresentado o setor A busca do tempo perdido, tendo por fechamento arqueológos situados no interior de um imenso pergaminho em forma de pirâmide maia.

Alas posteriores encenavam a sedução, o disfarce, o mundo subterrâneo da máfia, os anônimos transformados em super-heróis, estando o mistério urbano sintetizado em um grande tobogã negro abrigando a alegoria $\mathrm{Na}$ calada da noite sempre alerta..., na qual Homens-Aranha, Batman e Super-Homens desciam empinando skates, ladeados por espelhados arranha-céus em verde e prata. Trajando sobretudos e chapéus amarelos estiveram também o detetive cinematográfico Dick Tracy, o Triângulo das Bermudas, o ET de Varginha e o carro alegórico Área 5 I - zona militar que ficaria no deserto de Nevada, nos Estados Unidos. De tão misteriosa, a área manteria secreto, inclusive, o corpo do lendário Michael Jackson. Fechando o desfile, o setor dramático focalizava as camuflagens: do coelho na cartola, passando pela camuflagem tanto dos soldados no campo de batalha quanto de bichos e plantas que se transformam, confundindo os seus predadores ou presas. O pavão, símbolo 
da escola, encerrou a apresentação figurando O seu olhar vou iludir, em que a grande cauda negra portava cem pessoas fazendo movimentos coordenados para encenar as metamorfoses da natureza. ${ }^{21}$

Aclamado pela plateia na Passarela do Samba, esse desfile de 20 Io também foi consagrado pelo júri oficial do concurso com o título de campeão. Com o enredo É segredo, Barros pôde afirmar sua convicção: “[...] Perceber cada ângulo da plateia, antever o que pode provocar cada movimento, cada alegoria. Desconstruir o que está predeterminado, surpreender, ressignificar, transformar imagens conhecidas em novidades ao deslocá-las de lugar e inseri-las em outro contexto" (Barros, 2013: 44). O êxito obtido reafirma as soluções introduzidas por Paulo Barros, a despeito das críticas denunciando o "excesso de coreografia" em detrimento da espontaneidade da festa.

Uma vez mais, para o desfile de 20 I , ele tematizou o plano dos sentimentos, relacionando-os ao poder das imagens. Esta noite levarei sua alma, diferente das versões anteriores, abordou o poder das imagens audiovisuais de mobilizar as emoções humanas na fábula a respeito do medo. Os movimentos da Comissão de Frente - Pague para entrar, reze para sair - retratavam as desventuras do anjo da morte em tentar capturar o expectador cinematográfico, que, embora apenas estivesse em busca de diversão, via-se atormentado pelas situações de perigo, suspense e sofrimento. Notou-se, logo no início da apresentação, o cuidado dispensado pelo carnavalesco ao aperfeiçoamento dos meios de iludir e das condições de ver da plateia. A novidade esteve na alternativa cenográfica de introduzir a alegoria de uma grande sepultura cinza, de contornos góticos, com a aparência sombria na abertura do desfile, a qual contava com uma plataforma móvel, subindo e descendo. Disposta sobre essa base e comandada por um "lanterninha" de cinema vestido de amarelo, a Comissão de Frente evoluiu fantasiada de mortos-vivos, realizando truques com a própria cabeça: entre outros, escondiam-na dentro da casaca ou a carregavam no braço.

Logo a seguir, espectros brancos empurravam câmeras alegóricas para surgir, toda em preto e decorada por ícones macabros, com o predomínio de caveiras, A barca de Caronte - uma sala de exibição cinematográfica, em que a plateia eram almas vestidas de branco, que faziam movimentos coordenados encenando alegria e pavor sob a foice que compunha a grande escultura do anjo da morte. Acentuou-se nesse trabalho a tendência já presente em outros trabalhos do autor de justapor imagens impactantes, em detrimento de um eixo narrativo. Assim, se a continuidade do cortejo trouxe referências a filmes em que a questão do medo foi sobreacentuada, optando-se pelos títulos mais conhecidos como: Shogun, Avatar, Piratas do Caribe, Os caça-fantasmas, Priscila, a rainha do deserto, Transformers, Na montanha dos gorilas, O espantalho, o que se destacou foram as unidades cenográficas em que a encenação enfatizava truques acionados para captar a atenção do público. Em especial, 
chamou a atenção o carro Harry Potter, pois o ambiente do castelo medieval inglês, com suas altas torres dispostas nas laterais frontais, ladeado por centenas de esculturas de pequenas corujas iluminadas de rosa, tinha por centro a espécie de dança de uma grande mesa, subindo e descendo, carregando, em suas laterais, esculturas de magos que jantavam. Insere-se nesse desfile o conceito de "carro ação" para recriar o píer marítimo tomado para as locações do filme Tubarão (de Steven Spielberg, I975) E, ainda, o templo em ruínas, na Índia, que serviu de ambiente para a cena em que o protagonista dos filmes da série Indiana Jones (George Lucas e Steven Spielberg) é perseguido por uma pedra que rola em sua direção. Nas duas últimas situações, procurou-se simular os respectivos instantes de perigo encenados no cinema, ou seja, a luta do mergulhador contra o peixe assassino e a corrida do arqueólogo herói até o momento em que salta com uma corda para escapar da rocha. ${ }^{22}$

O carro alegórico homenageando o ator e diretor Zé do Caixão, no qual uma imensa tela de LED exibia cenas de filmes brasileiros, trazendo ao fundo três moinhos girando, em cujas hastes estavam vivas almas brancas, encerrou o desfile de 20 I. Esse momento, de alguma maneira, antecipou o dilema experimentado por Paulo Barros na preparação do desfile do ano seguinte. Em atendimento à encomenda que foi feita à direção da Unidos da Tijuca, decidiu-se homenagear os cem anos de nascimento do cantor Luiz Gonzaga. O desafio seria, então, adequar o estilo de Barros ao imperativo de narrar a história de uma pessoa. Desafio, pois a ele caberia tornar recíprocas a técnica de justapor imagens impactantes com a adoção de uma consistência diacrônica. Portanto, a alteração temática inseria o drama de conciliar "tradicional" e "moderno" no trabalho do carnavalesco. A saída encontrada foi, outra vez, apelar para os sentimentos, isto é, todo o conjunto cênico e coreográfico apresentado deu ênfase aos elementos intrínsecos à arte de Gonzaga que sensibilizaram os públicos. Desse modo, uma vez mais Barros apostava nos efeitos de adicionar e justapor signos e estéticas mediante as imagens que ofereceu e, com isto, reiterou a natureza audiovisual do gênero desfile de carnaval-espetáculo.

Como nas versões anteriores, a abertura do desfile fez a síntese da proposta. A coreógrafa Priscila Mota orientou os movimentos dos membros da Comissão de Frente, estilizando retirantes sertanejos, como variações rítmicas possíveis do fole da sanfona. Guiados pelo par Lampião e Maria Bonita, eles portavam pequenos acordeões, e suas danças exibiam trechos dos ritmos musicais forró, xote e baião até o momento em que, trocada a indumentária, os bailarinos se tornavam foles dançantes e subiam ao centro do palco montado sobre um tripé, tendo ao fundo a representação cenográfica da sanfona. Nesse instante, ocorria o ponto culminante da situação com a dança de uma frenética mola colorida. Mola encarnada pelo artístico húngaro Miklós Jancsó, contratado junto a um show de cassino de Miami. A partir daí teve início 
o desenvolvimento do enredo $O$ dia em que toda a realeza desembarcou na Avenida... para coroar o rei Luiz do Sertão. Antecipado pela ala A guarda de lampião, todo em prata com detalhes negros, o abre-alas Desembarque real era a representação cenográfica da área de saída de um aeroporto de onde surgiam os convivas da grande celebração - um diferenciado naipe de reis e rainhas (entre outros, estavam a rainha da Inglaterra, o rei Pelé, o rei cantor, Roberto Carlos, o rei Arthur da Távola Redonda, Napoleão, o astro pop Michael Jackson). E essa realeza de tão diferentes estirpes e origens tempo-espaciais consistiu no fio condutor de conto de fadas, o que se completava com a homenagem ao recentemente morto carnavalesco Joãosinho Trinta, ali celebrado como o "rei do carnaval". Reunidos, todos esses nobres rumaram para a coroação que deveria ocorrer no sertão.

As representações sociais das paisagens do Nordeste brasileiro adquiriram formas e cores ao chegaream em alas que aludiam à fauna e flora da região, mas também às suas iguarias típicas, como o prato "gerimum com jabá". Expondo exemplares de todos os produtos que são lá comercializados, o carro alegórico Mercado de São José propunha-se a ser uma réplica do original recifense, recriando seus contornos arquitetônicos envoltos pelos tons de verde. No prosseguimento da excursão, a "realeza" se encantou com a criação artística de barro de Mestre Vitalino. Antecedidos pelo casal de mestre-sala e porta-bandeira, em cor cerâmica, uma ala recriou todos os personagens confeccionados pelo lendário artesão pernambucano e, no desfecho desse setor dramático do enredo, uma alegoria no formato de um casebre de estuque e palha portando os utensílios da vida cotidiana rural sertaneja e com as rústicas ferramentas usadas pelos ceramistas, encenados por figurantes que se comportavam como marionetes. Na parte traseira do carro, pessoas vestindo indumentárias recriando os mesmos personagens de Vitalino equilibravam-se nas pontas de grandes gangorras que balançavam sobre as cabeças de outras, sentadas nas laterais, tocando foles prateados. Sobre o lombo de jegues, a realeza prossegue, encontrando com celebridades à maneira de Padim pade Ciço e vislumbraram a Missa do vaqueiro. Mesclando branco, dourado e amarelo, a cenografia dessa celebração combinou os traços tradicionais da fachada de uma igreja com um sofisticado carrossel de cavalos onde estavam sentados vaqueiros sobrevoando esculturas de reses dispostas na frente e nas laterais do carro alegórico.

Adentrando mais ainda a região Nordeste, a bordo de uma gaiola, cercada por grandes carrancas em vermelho, a realeza cruza o Rio São Francisco, das águas artificiais de onde saltavam igualmente falsas piranhas, para chegar, enfim, ao local de coroação do Rei do Sertão: um grande arraial junino, em que, outra vez, o destaque foi a sanfona dançante. O carro alegórico Festa junina estilizou o ambiente do festejo, sobressaltando cores e motivos pitorescos (barraquinhas, balões, bandeirolas e correntes), além dos figurantes 
vestidos ao modo dos integrantes dos grupos de quadrilha matuta. Ao centro, bailarinos se expunham ou se ocultavam abrindo e fechando o enorme fole. Ao final, a guarda de sonfoneiros deu passagem para o Rei do Sertão surgir frente a três grandes bolos negros em que deles asas brancas o saudavam. ${ }^{23}$

Ora, apesar da conquista do título do Grupo Especial das Escolas de Samba cariocas, em 20I2, Barros escutou muitas reclamações de que "não se viu Luiz Gonzaga no desfile". O teor das críticas sinaliza à escolha feita pelo artista no momento de conceber o projeto do desfile, ou seja, do conceito que fundamentou o enredo e sua execução plástico-visual. E esta conceituação, por sua vez, remete à metafísica que delimita o horizonte das expectativas do artista; metafísica definida pela centralidade gozada pelo apelo a imagens hábeis o suficiente para fisgar a atenção sensorial dos expectadores. Desse modo, para além da questão do nexo estabelecido entre os agenciamentos individuais movidos pela busca racional de um fim e a definição de uma linha institucional de conduta artística (Weber, I995), adquire relevo o problema da recriação mesma da forma carnaval-espetáculo.

Como propõe Luhmann (2005a: 55), a forma diz respeito à operação pela qual se estabelece uma distinção entre "dentro" e "fora", enfim, ao fazer a "diferença", a forma insere a possibilidade de um observador se diferenciar do seu entorno; com isso, anular-se-ia a indeterminação. Sob esse aspecto, a distinção esclarece ou estabelece limites à operacionalidade comunicacional, pois faculta a seletividade necessária à finalidade de gerar unidade de sentido em um sistema. Em se tratando do nosso objeto de interesse, a forma- espetáculo submete e mobiliza elementos na realização de um desfile. Ou seja, na condição de dispositivo regulador e de coordenação, o núcleo sistêmico constituído pela técnica de ludibriar se ocupa de selecionar as funções e propriedades internas ao sistema de práticas lúdico-artísticas desse gênero cultural. Portanto, a diferenciação social do evento, em meio à policromia da festa carnavalesca e da metrópole urbana (Farias, 20I2a), está na contrapartida da autocriação sistêmica perseverando sua competência de autodefinição, e esta se faz no ajuste das dimensões físicas, orgânicas, subjetivas e comunicacionais a partir do compromisso de gerar objetos estéticos que suscitem a cumplicidade de plateias.

Podemos concluir que o desfile de carnaval-espetáculo realiza-se como objetividade comunicacional na medida em que se consagra um "lugar" no qual podem ocorrer intervenções significativas e efetivas acerca do entendimento da vida social. Nesse caso, a diversão concretiza um sentido público e um padrão de regulação emocional. Os artefatos alegóricos são os ícones expressivos dessa objetividade; afinal, o que faz a alegoria carnavalesca nevrálgica é, justamente, não ser redutível aos discursos, proporcionar experiências extáticas, suscitando "um sentido de unicidade, de evocar uma sensação exaltada” (Cavalcanti, 20II: 235). A mesma objetividade avança para 
além dessas expressões, embora se permaneça no plano das trocas públicas de sentido, porque requer considerar os fatores que proporcionam sua funcionalidade e a consentem divertir, justamente, ao serem fruídas à luz de um padrão de regulação social das emoções.

Enveredar por esse último aspecto é ir em busca das tramas de interdependências humanas postas no entrosamento de condições de possibilidades sócio-históricas à posição estratégica da atuação do carnavalesco na interseção do sistema de práticas lúdico-artísticas do desfile carnaval-espetáculo e do complexo de mediações que o insere na cultura popular das mídias (Kellner, 200I: 138). Essas mediações compreendem toda sorte de recursos a saberes de outras práticas, facultando repercutir o traço amplo e múltiplo de experiências que atravessa a audiência do evento, cada vez mais aninhada nos mercados televisuais, vazando fronteiras locais e nacionais. Isto, porém, no instante mesmo em que o desfile compõe elos institucionais, dando formato a distintas práticas significativas humanas em extensões relacionais vastas, mas imaginariamente coligadas pela mesma camada de sentido que as ressignifica como entretenimento. Supomos que o sentido do mundo do entretenimento é realizado no rastro continuado de ritos seculares em que são erguidos altares para celebrar a vida pela vida.

Recebido em I7/04/20I4 | Aprovado em 3I/08/20I4

Edson Farias é professor do Departamento de Sociologia da Universidade de Brasília (UnB), onde coordena o grupo de pesquisa Cultura, Memória e Desenvolvimento, e do Programa de Pós-Graduação em Memória: Sociedade e Linguagem, da Universidade Estadual do Sudoeste da Bahia (UESB). É pesquisador do Conselho Nacional de Desenvolvimento Científico e Tecnológico (CNPq) e autor de, entre outros, Faces contemporâneas da cultura popular (2014); Ócio e negócio: festas e entretenimento-turismo no Brasil (20II); e O desfile e a cidade: 0 carnaval-espetáculo carioca (2006). 


\section{NOTAS}

I Texto apresentado ao Fórum O mundo das artes, práticas sociais e dimensão simbólica: pesquisas recentes, na mesa "Arte, feiras e mercado", durante o $36^{\circ}$ Encontro da Associação Nacional de Pós-Graduação e Pesquisa em Ciências Sociais (ANPOCS), Águas de Lindoia, MG, 2 I a 25 de outubro de 20I2. Agradeço os comentários e sugestões, em especial ao debatedor da sessão, Miguel Chaia. A elaboração da primeira versão deste artigo se deu no período entre março e julho de 20I2, quando estive como pesquisador convidado no Centro de Sociologia do Colégio de México, com bolsa de Estágio Pós-Doutoral (CAPES).

2 Outras intervenções com repercussão sobre a formação da opinião pública fizeram semelhante aproximação. Por exemplo, em fevereiro de 20I2, no seu blog, a dublê de cientista social e vereadora carioca Aspásia Camargo teceu comentários a respeito dos últimos desfiles das mesmas escolas de samba, ressaltando, uma vez mais, a aliança entre cultura popular e a nova economia estribada no conluio da informação com a tecnologia. Intitulado "Carnaval 20I2: vitória da indústria criativa", o texto reconhece a cúpula dos contraventores do jogo do bicho como sendo composta de "excelentes homens de negócio" ou que "entendem muito de samba e Carnaval". Isto, na medida em que sentencia estarem "as escolas de samba cada vez mais ricas e profissionalizadas" e ter o Sambódromo se firmado "definitivamente" como o "mais sofisticado desfile popular do Planeta”. Diagnostica, então, que, com a vitória obtida pelo carnavalesco Paulo Barros, à frente da campeã Unidos da Tijuca, teria vencido também "a ousadia das indústrias criativas que movimentam a economia popular da cidade,economia que estaria na contrapartida de investimentos (públicos e privados) "nesta grande festa da folia que, cada vez mais, aposta na inovação e nas novas tecnologias".

3 Entre 2005 e 2009, a Universidade Estácio de Sá manteve em funcionamento, no Rio de Janeiro, o curso tecnológico de gestão do carnaval. Segundo a instituição, a decisão de encerrar as atividades do curso deveu-se à "pouca procura" por parte de possíveis estudantes. 
4 Falando acerca do tempo, Norbert Elias observa: "O indivíduo, ao crescer, aprende a interpretar os sinais temporais usados em sua sociedade e a orientar sua conduta em função deles. A imagem mnêmica e a representação do tempo num dado indivíduo dependem, pois, do nível de desenvolvimento assim como das experiências que o indivíduo tem delas desde a mais tenra idade." (Elias, I998: I5).

5 Segundo a antropologia filosófica subjacente à epistemologia das ciências sociais que abraça Norbert Elias, os seres humanos "têm que adquirir, durante o seu desenvolvimento mediante a aprendizagem dos conjuntos de símbolos sociais com seus correspondentes significados e, portanto, retomam de seus antepassados um fundo social de conhecimento. Específicos conjuntos de símbolos sociais significativos têm, por sua vez, a função de meios de comunicação e meios de orientação e, sem a aprendizagem dos símbolos sociais dotados desta dupla função, não podemos nos converter em seres humanos. Permita-me aludir a uma breve caracterização das surpreendentes propriedades dos símbolos com funções de conhecimento: são intercambiáveis. Em um período histórico suas redes de significação podem ver-se remodeladas com o fim de lograr uma simbolização melhor que a que anteriormente existia. Sua rede pode ser utilizada para cobrir áreas e objetos, ou para estabelecer conexões previamente não cobertas por eles e, portanto, inimagináveis e desconhecidas até então para os seres humanos, porém podem também languidescer e se degradar até o ponto em que as áreas que cobriam podem chegar a ser de novo uma realidade desconhecida e inimaginável" (Elias, I994: 54-55, minha tradução).

6 Tomamos de empréstimo a Bourdieu a noção de conhecimento pelo corpo (200I: I590): "O mundo me abarca, me inclui como uma coisa entre as coisas, mas, sendo coisa para quem existem coisas, um mundo, eu compreendo esse mundo; e tudo isso, convém acrescentar, porque ele me engloba e me abarca: é de fato por meio dessa inclusão material - frequentemente despercebida ou recalcada - e de tudo que dela decorre, ou seja, a incorporação das estruturas sociais sob a forma de estruturas de disposições, de chances objetivas sob a forma de esperanças e anteci- 
pações, que acabo adquirindo um conhecimento e um domínio práticos do espaço englobante (sei confusamente o que depende e o que não depende de mim, o que é "para mim" ou "não é para mim" ou "não para pessoas como eu", o que é razoável para eu fazer, esperar, pedir)".

7 Recorremos a Heidegger (2002) quando o autor define a essência da técnica, no sentido tecnológico, em função de um dispositivo voltado ao preenchimento dos propósitos humanos. Não compreendendo um fazer, uma destreza, mas a capacidade de revelar os entes. Importa então o já convertido em algo ou a própria conversão. Também nos calcamos no mesmo autor no tocante à concepção de arte ao modo de um projeto pelo qual se propõe um mundo, gerando o artista e seus “preservadores" - o público (Heidegger, 2003: 27-69).

8 O gênero corresponde ao conjunto sistemático de regras que formaliza, ao codificar, as expectativas entre emissor e recepção de um bem expressivo, sabendo estarem ambos os polos encadeados no contexto de uma mesma situação de comunicação. Propõe-se que, se o gênero inscreve um conjunto específico de disposições, com a finalidade de possibilitar uma estabilidade necessária para o ato expressivo-comunicacional se tornar válido e inteligível, ele abre uma janela de oportunidades para o ajuste previsto dentro do contrato de sentidos com a audiência e requer o permanente entrosamento da criação coletiva com os agenciamentos, uma e outros se confrontam e se complementam de acordo com as vicissitudes históricas que as conformam numa teia de múltiplos relacionamentos inseridos em interdependências sociofuncionais alargadas (Martín-Barbero, I987: 239-242).

9 Em entrevista concedida para o autor, a dublê de cenógrafa teatral e carnavalesca Rosa Magalhães foi categórica ao dizer: "A informação tem que ser passada direta: as coisas devem ser mostradas com clareza. O importante é que as pessoas reconheçam rapidamente o que se quer mostrar" (Farias, 2006: 294).

Io Descrevendo o lugar do carro alegórico nas apresentações das escolas de samba, em especial o segredo 
que os costuma envolver antes do evento, uma vez mais Rosa Magalhães ressalta: "Enquanto as fantasias são mostradas ao público - no período anterior aos desfiles -, os carros alegóricos são guardados a sete chaves, como um segredo de Estado. Embora seja apenas um item de julgamento, são muito valorizados, inclusive por entusiasmarem os componentes" (Magalhães, I997: 8I).

I I Na reconstrução textual nos valemos de observação participante tanto nos locais de elaboração das alegorias e fantasias (barracões) quanto nos dias de desfiles na Marques de Sapucaí, utilizando máquinas fotográficas e filmadoras. Realizamos entrevistas semiestruturadas. Também fizemos consultas a fontes primárias - sinopses de enredos, jornais e revistas. E, ainda, tivemos acesso a vídeos das apresentações comentadas na plataforma audiovisual da Internet, o Youtube.

I 2 O desfile de carnaval reúne em concurso setenta escolas de samba, no Rio de Janeiro, divididas em cinco grupos. A partir do grupo principal - denominado "especial" -, o procedimento de seleção nessa hierarquia implica a elevação das primeiras colocadas ao grupo superior e, na mesma medida, no rebaixamento para o grupo inferior das últimas colocadas.

I3 Descrição possível a partir do Youtube, disponível: <http:// www.youtube.com/watch? $v=z \mathrm{Nb}_{4} \mathrm{PKTs}$ _8 $>$. Acesso em I6 set 2012 .

I4 Nos comentários tecidos sobre a apresentação da Unidos da Tijuca, durante a transmissão televisual da Rede Globo, a carnavalesca Maria Augusta Rodrigues fez questão de ressaltar que, com o trabalho de Paulo Barros, o carnaval do Rio de Janeiro, como uma espécie de organismo, dizia: "eu estou vivo e sou capaz de me renovar".

I5 Descrição possível a partir do Youtube, disponível em: $<$ http://www.youtube.com/watch?v=9xeIIGG2dlo\&featur e=relmfu>. Acesso em I8 set 2012 .

I6 Trata-se mesmo de um procedimento recorrente, basta lembrar que a elaboração dos enredos, desde o início da história dos desfiles, recorre a livros historiográficos ou romances. Da década de 1980 em diante sobressai o apelo ao acervo da cultura popular de massa. O carnavalesco 
Fernando Pinto foi pioneiro a respeito, quando, em I985, justificando ser o espaço cênico do Sambódromo a moldura dentro da qual as texturas, formas, cores e temas das criações devem obedecer ao princípio de materializar delírios em imagens visuais de efeitos impactantes, ele partiu da leitura dos autores de ficção científica Arthur Clark e Isaac Asimov, além da série cinematográfica Flash Gordon e, principalmente, do filme de Stanley Kubrick, 200I, uma odisséia no espaço, a partir do qual concebeu o enredo 200I Ziriguidum, um carnaval nas estrelas: "É verdade que sem um bom samba, não há Carnaval que resista. Mas o Carnaval do Sambódromo, que é um espaço fixo, privilegia os efeitos espetaculares, o delírio das imagens. Com isso, as escolas de samba precisam dar realce às fantasias e aos carros alegóricos. É preciso levar cores brilhantes para o desfile, para conquistar as pessoas que estão chegando agora ao Carnaval [...]. Para dar maior liberdade, despi bastante as pessoas que desfilam e fiz com que os carros alegóricos se transformem em objetos articulados. Tudo se mexe no Carnaval da Mocidade, não há nada que seja simplesmente arrastado, sem brilho, na pista. As naves, bichos e planetas se movimentam sem parar, imitando a linguagem dos videogames, das revistas em quadrinhos e dos shows de rock (Veja, 27/2/1985).

I7 As informações arroladas sobre os movimentos coordenados foram obtidas durante entrevista concedida ao autor deste texto (em 22 de agosto de 2006) pelos coreógrafos Marcelo Sandryni e Roberta Nogueira, responsáveis pelos movimentos nos desfiles assinados por Paulo Barros, os quais fizeram questão de frisar que não se tratava de meras coreografias, mas seriam movimentos de um balé, obedientes ao curso da letra do samba-enredo.

I8 Descrição possível a partir do Youtube, disponível em: $<$ http://www.youtube.com/results?search_query=Unidos + da + Tijuca $+2006 \&$ oq $=$ Unidos + da + Tijuca $+2006 \& g s \_l=y o u$ tube.I2...I34475.I449I8.0.I46402.2I.I5.0.0.0.0.0.0..0.0...0.0 .... Iac. I>. Acesso em og set 2012.

I9 Entrevista de Paulo Barros ao autor (20 de agosto de 2006).

20 A ideia de trabalhar com os sentimentos apareceu no trabalho de Barros, para o desfile de 2008 , quando propôs o enredo Arrepio, ainda na Unidos da Viradouro, explorando 
fontes diversas capazes de gerar essa sensação (Barros, 2013: 53-55).

2I Descrição possível a partir do Youtube, disponível em: <http://www.youtube.com watch? v=ucN7Ohv_8 Ac \& feature $=$ g-vrec $>$. Acesso em 03 ago 2012.

22 Descrição possível a partir do Youtube, disponível em: http://www.youtube.com/watch?v=sH6LSDTI5O4>. Acesso em I5 ago 2012.

23 Descrição possível a partir do Youtube, disponível em: <http://www.youtube.com/watch?v=ozIV4UxGP7Q>. Acesso em 06 jul 2012.

\section{REFERÊNCIAS BIBLIOGRÁFICAS}

Argan, Giulio Carlo. (2004). Imagem e persuasão: ensaios sobre o barroco. São Paulo: Companhia das Letras.

Barros, Paulo. (2013). Sem segredo: estratégia, inovação e criatividade. Rio de Janeiro: Casa da Palavra.

Becker, Howard. (20I0). Mundos da arte. Lisboa: Livros Horizontes.

Bell, Clive. (2009). Arte. Lisboa: Edições Texto \& Gráfica. Baxandall, Michael. (2006). Padrões de intenção: a explicação histórica dos quadros. São Paulo: Companhia das Letras.

Baxandall, Michael. (I99I). O olhar renascente. Rio de Janeiro: Paz e Terra.

Bourdieu, Pierre. (2008). A distinção: crítica social do julgamento. São Paulo/Porto Alegre: Edusp/Zouk.

Bourdieu, Pierre. (2004). El baile de los solteros. Barcelona: Anagrama.

Bourdieu, Pierre. (200I). Meditações pascalianas. Rio de Janeiro: Bertrand.

Bourdieu, Pierre. (I999). Contradições da herança. In: Nogueira, Maria Alice \& Catani, Afrânio (orgs.). Escritos de educação. Petrópolis: Vozes.

Bourdieu, Pierre. (1996). As regras da arte. São Paulo: Companhia das Letras.

Calabrese, Omar. (I986). A linguagem da arte. Rio de Janeiro: Globo. 
Cavalcanti, Maria Laura V. de C. (20II). "Alegoria em ação". Sociologia \& Antropologia, I/I, p. 233-249.

Cavalcanti, Maria Laura V. de C. (2004). Carnaval carioca: dos bastidores ao desfile. Rio de Janeiro: Ed. UFRJ.

Cavalcanti, Maria Laura V. de C. (I999). O rito e o tempo: ensaios sobre o carnaval. Rio de Janeiro: Civilização Brasileira.

Cunha, Maria Clementina P. (200I). Ecos da folia: uma história social do carnaval carioca entre I880 e I920. São Paulo: Companhia da Letras.

Elias, Norbert. (2006). Estudos sobre a gênese da profissão naval. In: Neiburg, Federico \& Waizbort, Leopoldo (orgs.): Norbert Elias: escritos \& ensaios. Rio de Janeiro: Zahar, p. 89-II2.

Elias, Norbert. (1998). Sobre o tempo. Rio de Janeiro: Zahar. Elias, Norbert. (I998a). Envolvimento e alienação. Rio de Janeiro: Bertrand.

Elias, Norbert. (I994). Conocimiento y poder. Madri: La Piqueta.

Ewen, Stuart. (I988). All consuming images: the politics of style in contemporary culture. Nova York: Basic Books.

Faria, João Roberto. (2013). História do teatro brasileiro. São Paulo: Perspectiva/SESCSP (vol. I).

Farias, Edson. (2013). O desfile de carnaval nas tramas da cultura popular urbana carioca. Cadernos do CRH, 66/28, p. I57-I77.

Farias, Edson. (20I2). Personalidade artística nos negócios mundanos: a celebração do "gosto do povo" em Joãosinho Trinta. In: Farias, Edson \& Leão, Andrea Borges (orgs.). Dossiê Norbert Elias: releituras. Sociedade \& Estado, 26/3, p. 594-625.

Farias, Edson. (2012a). "Hoje é festa na metrópole”: considerações sobre expressões lúdico-estéticas no carnaval carioca. In: Rubim, Linda \& Miranda, Nadjá Magalhães (orgs.). Estudos da festa. Salvador: EDUFBA (Coleção Cult), p. 49-76.

Farias, Edson. (20II). Ócio e negócio: festas populares e entretenimento-turismo no Brasil. Curitiba: Appris. 
Farias, Edson. (2006). O desfile e a cidade: o carnaval-espetáculo carioca. Rio de Janeiro: E-Papers.

Featherstone, Mike. (I99I). Consumer culture \& postmodernism (theory, culture and society). Londres: Sage.

Feijó, Carlos \& Nazareth, André. (20II). Artesãos da Sapucaí. São Paulo: Olhares.

Fernandes, Nelson Nóbrega. (200I). Escola de samba: sujeitos celebrantes e objetos celebrados. Rio de Janeiro: Secretaria das Culturas.

Gombrich, Ernest H. (1995). Arte e ilusão: um estudo da psicologia da representação pictórica. São Paulo: Martins Fontes. Gomes, Fábio \& Guimarães, Stela Villares. (2008). O Brasil é luxo: trinta carnavais de Joãosinho Trinta. São Paulo: CBPC. Guimarães, Helenise. (I990). Carnavalesco: o artista que faz escola. Dissertação de mestrado. Escola de Belas Artes/ Universidade Federal do Rio de Janeiro.

Heidegger, Martin. (2003). A caminho da linguagem. Petrópolis: Vozes.

Heidegger, Martin. (2002). Sobre a técnica. Petrópolis: Vozes. Heinich, Nathallie. (2008). A sociologia da arte. Bauru, SP: EDUSC.

Kellner, Douglas. (200I). A cultura da mídia. Estudos culturais: identidade e política entre o moderno e o pós-moderno. Bauru, SP: EDUSC.

Kothe, Flávio R. (20II). Ensaios de semiótica da cultura. Brasília: Ed. UnB.

Lima, Roberto Kant de \& Lima, Magali Alonso de. (I99I). Capoeira e cidadania: negritude e identidade no Brasil republicano. Revista de Antropologia, 34, p. I43-I82.

Lipovetsky, Gilles \& Serroy, Jean. (2009). A tela global: mídias culturais e cinema na era hipermoderna. Porto Alegre: Sulina.

Luhmann, Niklas (2005). A realidade dos meios de comunicação. São Paulo: Paulus.

Luhmann, Niklas (2005a). El arte de la sociedad. Cidade do México: Herder, 2005.

Magalhães, Rosa. (I997). Fazendo carnaval. Rio de Janeiro: Lacerda Editores. 
Manguel, Alberto \& Guadalupi, Gianni. (1987). The dictionary of imaginary places. San Diego/Nova York/Londres: Harcourt Brace \& Company.

Martín-Barbero, Jesús. (I987). De los medios a las mediaciones. Cidade do México: Gustavo Gilli.

Moraes, Eneida de. (I958). História do carnaval carioca. Rio de Janeiro: Civilização Brasileira.

Pereira, Leonardo A. M. (I994). O carnaval das letras. Rio de Janeiro: Secretaria Municipal de Cultura.

Roberts, David. (2003). Illusion only is sacred: from the culture industry to the aesthetic economy. Thesis Eleven, 73, p. 83-95.

Ruiz, Roberto. (I98I). O teatro de revista no Brasil. Rio de Janeiro: Minc/INACEN.

Santos, Nilton S. (2009). "Carnaval é isso aí. A gente faz para ser destruído!”: carnavalesco, individualidade e mediação cultural. Rio de Janeiro: Apicuri.

Turano, Gabriel da Costa. (20II). A visualidade da escola de samba na década de i930: inovação, transformação, reconfiguração. Textos Escolhidos de Cultura Popular, 8/2, p. I33-I 42 .

Weber, Max. (I995). Os fundamentos racionais e sociológicos da música. São Paulo: Edusp. 


\author{
Palavras-chave \\ Artistas carnavalescos; \\ Técnicas do ludibrio; \\ Herança intergeracional; \\ Carnaval carioca; \\ Entretenimento.
}

Keywords

Carnival artists;

Tecniques of deceiving; Intergenerational heritage;

Carioca carnival; Entertainment.

\section{O SABER CARNAVALESCO: CRIAÇÃO, ILUSÃo E TRADIÇÃO NO CARNAVAL CARIOCA}

\section{Resumo}

Este texto aborda a transmissão de saberes e práticas entre diferentes gerações de carnavalescos. Este ofício se torna fundamental na afirmação do entretenimento como integrante do padrão societário e cultural da modernidade, tal como experimentada na cidade do Rio de Janeiro, nas últimas décadas do século XX e no limiar do presente século. Esse saber relativo à estética barroca dos efeitos e excessos visuais se inscreve na problemática da permanência do que poderíamos denominar de uma diferencialidade funcional. Ao mesmo tempo, observamos como esta diferencialidade repercute a perenidade adquirida por um padrão de conduta artística em meio às alterações de interesses e ideias no desfile das escolas de samba.

\section{THE CARNIVAL KNOWLEDGE: CREATION, ILLUSION} AND TRADITION IN THE CARIOCA CARNIVAL

\section{Abstract}

This text deals with the transmission of knowledge and practices between different generations of carnival artists. This activity occupies a central role in the business of entertainment as part of the social and cultural patterns of modernity as experienced in Rio de Janeiro in the late 2oth century and early 2 ist century. This knowledge relies on baroque aesthetic effects and visual excesses and indicates the permanence of what might be called a functional differentiality. At the same time, we see how all this differentiality affects the continuity of a pattern of artistic conduct that emerges amid the continuous changes of interests and ideas in the parade of samba schools. 